\title{
'Abd al Wahhab ben 'Abd al Raḥmān ben Rostem
}

\section{Agabi}

\section{OpenEdition}

Journals

Édition électronique

URL : http://journals.openedition.org/encyclopedieberbere/781

DOI : 10.4000/encyclopedieberbere.781

ISSN : 2262-7197

\section{Éditeur}

Peeters Publishers

\section{Édition imprimée}

Date de publication : 1 novembre 1984

Pagination : 73

ISBN : 2-85744-201-7

ISSN : 1015-7344

\section{Référence électronique}

C. Agabi, «'Abd al Wahhab ben 'Abd al Raḥmān ben Rostem », Encyclopédie berbère [En ligne], 1 | 1984, document A13, mis en ligne le 01 décembre 2012, consulté le 05 octobre 2020. URL : http://

journals.openedition.org/encyclopedieberbere/781 ; DOI : https://doi.org/10.4000/ encyclopedieberbere.781

Ce document a été généré automatiquement le 5 octobre 2020.

(c) Tous droits réservés 


\section{'Abd al Wahhab ben 'Abd al Raḥmān ben Rostem}

\section{Agabi}

Iman rostémide de Tahert*, fils et successeur du fondateur de la dynastie. Sous son règne la ville de Tahert s'agrandit et se peupla (168/785-208/824). 'Abd al Wahhāb eut un début de règne difficile, à Tahert des mouvements populaires furent suscités par les Nokkarites dont la doctrine tendait à mettre l'iman sous le contrôle d'une assemblée. 'Abd al Wahhāb eut à combattre une autre secte, celle des Wāsilites qui se recrutaient surtout chez les Howāra et les Luāta. Mais son effort porta surtout sur le Jbel Nefussa. Avec l'aide des tribus berbères ibadites il assiégea Tripoli et contrôla tout le sud de l'Ifrīqiya, de Zouara au pays de Kastilia (Jerid).

\section{BIBLIOGRAPHIE}

Abu Zakarīyā al Wargalani. Chronique. Traduction. R. Le Tourneau. Rev. afric. t. 104, 1960, p. 99-176 et 322-390.

\section{INDEX}

Mots-clés : Algérie, Biographie, Moyen Âge 